\title{
Reconstruction of Maqasid Syariah Value's in the Islamic Political Culture
}

\author{
F Khumaini $^{1}$, M. Sholihin ${ }^{2}$ \\ ${ }^{1}$ Lecturer in Islamic education, Faculty of Government, IAI Sunan Giri Bojonegoro, Indonesia \\ ${ }^{2}$ Lecturer on Hadith, Ushuluddin Faculty, IAI Bani Fattah Jombang, Indonesia \\ Email: khumkhum38@gmail.com
}

\begin{abstract}
Islam is a complete view of life, that is the integral of religion with politics, law and community. The reform of society requires referring to Islam that is a reform of religion-politic taking inspiration from the Quran and Sunnah. In this current situation, the unfinished problem is the practice of corruption that takes personal or group advantage. It happens because of the disappearance of values of aqida and the way of thinking which contain s Islamic purposes, tillit destruct $s$ the moral system of society and economic gap. The improvement of Culture and political purpose fundamentally are needed both philosophically and practical. The term politic means care (ri'ayah), reform (ishlah), establish (taqwim), guidance (irsyad) and educate, Thus there is a common with the meaning of maqasid Syaria fundamentally, that emphasize s the improvement continuously in the system or role related to the personal culture or in society, and as an instrument of social design that produce an individual and society in increasing the quality of education, morals and aqida in.
\end{abstract}

Keywords: islam; maqasid syariah; political culture

\section{INTRODUCTION}

The history of Muslims is a dynamic part of the Islamic experience. The success of Islam in the early days gave the Muslims the revelation of the mission of revelation and the starting point for understanding Islam in the modern world must be seen from the historical experience of Muslims. The long interaction between the changing conditions and the Qur'anic message of permanent nature provided patterns and ideals and lasting influence, and from these interactions also provided the basis for the Islamic dimension of a modern Islamic analysis. The basis for Islamic awareness of historical experience is stated in the Qur'an itself, as the Qur'an places great emphasis on the facts, that the historical process is not neutral in relation to nations and groups of people [1]. The history of Islamic power is always in line with certain ideologies as the majority's understanding, an ideology derived from the understanding of Islamic teachings, and one of the functions of the ideology is as a political or policy tool in social engineering efforts.

In the broader dimension of Islamic heritage, there are significant elements, which can be separated into two main themes: common elements of the continuation of the Islamic experience, and the various fundamental elements that exist in the Islamic community. Each of these themes influences the attitude of the Muslim community in the face of the challenges that come with changing conditions in the world and within the Muslim community itself [1]. 
Islam is a complete and complete view of life. Religion is integral to politics, law, and society. The revival of the socio-political system of society required a return to Islam, a religious-political reform, which drew inspiration from the Qur'an and the first major Islamic movement led by the prophet Muhammad [2].

In keeping with the changing and evolving times, the issues to be addressed are Islam as a cultural producer, and Islam as a social engineering tool with a maqasid and political approach. Because essentially political behavior must be based on Islamic values and goals (maqasid).

\section{METHOD}

The type of research used is library research. The main objectives of this research in the field of Maqasid are the book of Maqasid asy-syari'ah al-Islamiah by Muhammad Thohir Ibn Asy- Syur, and the book Contributing Islamic Law Through the Syariah Maqasid of Jasser Auda. Whereas in politics is the book of Al-Aql as al-'asiasi al'Arabi by Muhammad Abid al-Jabiri .

The approaches used in this study are descriptive and qualitative . Diskri approach ptif- qualitative used to see tahapan- stage the concept of syariah of some classic literature, and historical approaches are used to seeing political phenomenon in the history of Islam.

\section{RESULT AND DISCUSSION}

\section{A. Integration of Islamic Law and Politics in the Early Middle Ages}

A simple picture of Islam as a cultural producer [3] can be seen in the early days of the Islamic birth, that is, when Islam brought new norms to change the beliefs and morals of the people of Makkah, and Islam as a social engineering tool in the Medina period through the political policy of the prophet in regulating the social system of society. These norms were born with the revelation given to the Prophet Muhammad (saw). The ideals of Islam began with the incorporation of faith and ethical aspects into its embrace. He began with psychiatric education for individuals, families, and communities, eventually creating a harmonious relationship between all members of the community in which one of his mirrors the outward prosperity [4]. Islam produces norms that originate from revelation, and still accommodates good local cultural values.

Through the observance of God's law, instilling moral values in its members, and the creation of brotherhood, Islam has played a major role in integrating human society. A series of concentric circles can describe different areas of relationships. At the center point is the relationship between the individual and God. Around the central area is the family circle, then the next community is a village or city, then the community circle (wathan) in the general sense, followed by the circle of the Islamic community (ummah), and the last is the circle of humanity and all beings in the whole world. Just as every circle in the series has a single center, each relationship remains based on the basic relationship between man and God [5]. In addition to these two patterns of relationship, there is a human connection with nature.

It is important to remember that the Islamic empire resides in the hearts of all men, men and women and not just in the form of worldly power. In order to balance the life of the ummah and the leadership of this "spiritual empire", it is important to remember the message that is the basis of Islamic revelation and the sending of prophets as apostles to the world. In one of the most famous hadiths, the prophet says, "I am sent in order to perfect (for you) the moral." the role of the Islam community has always been within the framework of possible achievements of welfare and moral perfection. And Muslim thinkers, like al-Farabi, as well as Plato, divide society according to their ability to provide a conducive environment for perfecting the members' moral and spiritual qualities. From an Islamic point of view, the value of a society in the eyes of God rests on the quality of its 
virtues, its moral height, and not on the amount of power or wealth [5]. The changes and developments of the times bring new issues, which require the re-interpretation of the meaning contained in the revelation, as well as the related sciences. Therefore, the most basic capital is, isla $\mathrm{h}$ al-fikr on a regular basis so that Islamic goals can be applied in accordance with the development of the ages through personal and group policy, so that Islam produces a culture of personal quality and a society that contains the values of virtue, and height moral.

\section{B. Understanding and Principles of the Syariah Maqasid}

Maqasid includes the wisdom behind the law, such as enhancing social well-being as one of the wisdom behind zakat, raising awareness of the presence of Allah Almighty as the wisdom behind fasting .

The Maqasid are also good goals that Islamic law wants to achieve, by opening up a path to good, or closing the road to evil. Thus, Maqasid preserves the mind and the human soul explains the strict prohibition on alcoholic beverages and other alcoholic beverages. Maqasid is also regarded as a set of divine ideas and moral concepts that are fundamental to Islamic law, such as justice, human dignity, free will, generosity, convenience, and community cooperation. Maqasid represents the relationship between Islamic law and the current ideas of human rights, development and civilization [6].

The word Maqasid is derived from the Arabic language هـ قاصد, which is a plural form of the word مقدص مد w which means intent, goal, principle, intention, purpose, end goal [6]. Maqasid is about prosperity, prosperity and well-being that are the fruit or essence of the end result of human work and effort, the desire of the soul, and the desire of every human being [7]. As Maqasid asy-Syari'ah is a term used to represent the meanings, purposes and wisdom covered in the rules that encompass various laws and systems. The system that governs humanity, family, society, organization and government.

There are generally five basic principles of classical maqasid concepts: hifzul-nasli (hereditary protection), hifzul-aqli (protection of the mind), hisful-irdi (protection of honor) or hifzul-nfsi (protection of the soul), hifzuddin (protection of religion) and hifzulmali (property protection). In the contemporary Maqasid concept, there is a discourse on the addition of terms, from 'protection' and 'protection' to 'development' and 'human rights'.

Traditionally hifzul-nasli (protection of posterity) is one of the goals of Islamic law. al-Amiri expressed it at the outset of his attempt to illustrate the theory of maqasid need, with the term 'law for acts of violation of morality'. Al-Juwaini developed al-Amiri's version of 'criminal law' ( muzajir ) into 'guardianship' ( 'ismah )' which was expressed by al-Juwaini with the term 'hifz al-furuj' , meaning guarding the genitals [6].

Similarly, hifzul-aqli (protection of the mind) which has until recently been limited to the purpose of the ban on alcoholic beverages in Islam, has now grown by incorporating 'the development of the scientific mind', the 'journey of demanding knowledge', 'against the taqlid mentality' and 'prevent foreign experts'.

Similarly, hisful-irdi (honorary protection) and hifzul-nafsi ( physical protection of the soul), hifzu-irdi has been a central concept in Arab culture since the pre-Islamic period, quarreling with factions, quarreling with gangs about ' defiling their honor' . In the hadith, Prophet Saw. Explaining that 'the blood, treasure, and honor of every Muslim is' illegal', which cannot be violated'. More recently, however, the expression 'protection of honor' in Islamic law has been gradually replaced by 'protection of dignity and dignity', even replaced by 'protection of human rights' as a maqasid in Islamic law [6].

Hifzuddin (the protection of religion) in the terminology of al-Ghazali and al-Syatibi, had 
its roots in al-Amiri's version of 'punishment for abandoning true belief'. However, lately, the same theory for the maqasid of Islamic law has been redefined into a completely different concept, namely 'freedom of faith' (Ibn asSyur). Or 'freedom of belief' in other contemporary expressions. Organizers of this view often cite the Qur'anic verse: 'no compulsion in religion' as a fundamental principle, rather than understanding it as a popular and inaccurate view, calling for 'punishment for apostasy' (hadd al-ridah) which is frequently mentioned in reference traditional references in the context of hifzuddin or 'religious protection'.

Lastly, hifzulmali (protection of property) al-Ghazali version along with al-Amiri's 'punishment for theft' and al-Juwaini's 'money protection' have recently evolved into familiar socio-economic terms such as 'social assistance', 'economic development', 'distribution of money', 'prosperous society' and 'reduction of socio-economic differences. This development has enabled the use of maqasid to drive the economy, which is needed in most Muslim-majority countries [6].

\section{Understanding Politics}

In Arabic the word political means is to act on something right or right [8] and can be interpreted as 'policy'. In other words it can mean taking care of, training, nurturing, and educating. If politics (assiyasah) is applied in the management and training of the herdsmen. Politics is shepherding. Then, in its developmental stages the word is used to regulate or shepherd people in all its affairs. The perpetrators or herdsmen of the management of these human issues are called politicians (siyasiyun) who are called politicians. In Arabic literature called the leader or ulil amri care (yasuusu) or nurture, manage, organize, and take care of people with all his affairs. Similarly in the dialogue arab arises the following statute: "How can the people be taken care of (masuusah) if those who manage it are moths (legalized). This statute means that it is possible for the people to be well and prosperous if their leader is damaged like a moth that eats wood. Thus, politics has the meaning of preserving (ri'ayah), improving (ishlah), upholding (taqwim), giving direction or direction (irst) and educating or advancing [9]. Naturally, there is a common goal between Islamic maqasid and politics that is personal, community, and community.

Islam is believed to be relevant and integral to politics, law, education, social and economic life. The aforementioned things are not viewed as secular institutions or areas of 'worldly' living, but rather as areas of Islamic religion, based on the belief that Islam is a view of life, and therefore religion and society are interrelated [2].

\section{Reconciling Sharia Maqasid Values in Islamic Political Culture}

The discussion of Islam and politics to this day remains a hot topic. Researchers on Islam and politics have actually come to the conclusion that, in matters of Islam and politics, there are at least three sects of thought. The three sects are Islamic formalism (Islamic and political unification), Islamic subtlety (Islamic ethics in politics) and secular (strictly Islamic and political separation) [10]. However, the real issue in law, as in politics in general, is the question of change. How much change in Islamic tradition is needed, how far can it leave it? Conservatives view the need for no fundamental change. The neotraditionalist, who in principle acknowledge the ijtihad, in practice do little to reinterpret it. They reflect the taklid's mentality. Although in principle they acknowledge the necessity and possibility of change, yet they strongly refer to the traditional law until they are reluctant to support fundamental changes [2]. The next change is in the tradition of Islamic political tradition.

According to Muhammad Abid al-Jabiri, the earliest gateway to understanding Islamic 
politics was about the public imagination

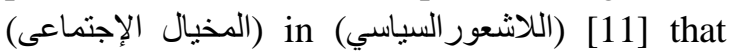
Muslims do in politics. The classification of the motives of Islamic political practice according to Jabiri is as follows:

First, (ال ع ق يدة) [12]: political views of preaching with the ideological motives of the early spread of Islam in Makkah and Medina. From the ideological element of the socialist sitemap of society [11], thus forming a Muslim community (Ummah), and in the next stage a Medina state. This ideological element is one of the political motives of Muslims. The difference is that in the days of the prophet the ideological values (aqidah) became the main goals and motives in his political policy. After the death of the political prophet the preaching with ideological values was used for the purpose of justifying the opinion, fatwa or political policy of an Islamic group with another group of Muslims to gain power. Or in other words, using religious symbols as polytechnic tools.

Second, (ال قبد بلة), political views by forming a group or community of faith (Ummah) made up of different elements of the group, this is to distinguish it from other communities, so it is prone to conflict with other groups or communities outside of Islam [11]. And after the death of the Prophet, an element of ethnic violence in the Arab tradition came back to determine who had the right to replace the Prophet.

Third, ( ال غ ذن يمة), it is the dominant element that creates conflict between the Muslim community and the rest of the community is the power over potential economic benefits. The presence of the prophet would be to the detriment of the Quraish people who at that time dominated trade in the Makkah region which was the center of economic transactions of various ethnic groups [11]. In addition, the teachings of monotheism carried by the prophets undermine the economic benefits of selling idols which are one of the important sources of the economy. In the case of
Muslims themselves conflicts over the ghonimah element occur over the confiscation of property, as well as the economic benefits of post-war Islamic territory expansion.

The Muslim community in the early prophetic era, until after emigration from Makkah, was the basis of religion and belief [13]. The arrival of Islam in Medina preceded the formation of a religious society and a politically connected policy [13]. All political decisions of the prophets are based on the basis of their usefulness, which is based on religious values [12].

While the prophet was alive, all the problems that had arisen among the Muslims could still be resolved, with the prophet as the final decision maker. However, the problems became more complex after the death of the prophet, the leadership, the ubudiyah and the social issues that arose in the community.

After the leadership of khulafaurrasyidin, the element of ethnicity, blood relations (qabilah) was deeply embedded in the politics of Islamic power, which is marked by the establishment of the Umayyad Dynasty. The Umayyad dynasty derives its lineage from Umayah ibn Abdi Syams ibn Abdi Manaf. He was a prominent figure in the Javanese period, in association with his uncle Hashim ibn 'Abdi Manaf. Umayah and Hashim were influential in the socio-political processes of the Javanese period, but Umayah was dominant. This is because he is a rich businessman, and has a wealth of resources. Although wealth and wealth were the dominant factor in winning the hearts of the Quraysh, Hashim could not balance his nephew [3], The teachings of monotheism (ideology) brought by the Prophet Muhammad, who was a descendant of the Hashim, would undermine the sale of idols that were the source of the economy (ghanimah) and the wealth of the Umayah ibn Abdi Shams. Weakening economic resources will automatically weaken their influence on the ignorant people. 
The collapse of the Umayyad dynasty marked the establishment of the Abbasid Dynasty, the dynasty being taken from the name of one of the prophets of the Prophet Muhammad SAW named al-Abbas ibn Abd al-Muttalib ibn Hashim. The Abbasid people felt more entitled than the Children of Umayah to the caliphate of Islam, because they were from the branch of the Hashim who were of lineage closer to the prophet. According to them, the Umayyas forcibly took control of the caliphate through the Siffin war tragedy. Therefore, in order to establish the Abbasid Dynasty they staged a rebellion against the Umayyad Dynasty [3].

In history it can be seen that politically, Islam (ideology) has become a tool for gaining power over economic potential (ghanimah), argued by the Arab clans (qabilah). Islam as a symbol of the teaching of God does not appear to stand out in the political movement that is taking place. Therefore, it is necessary to reconcile (Islah) the values of Islam in politics, towards a vibrant and enlightening political movement.

The main theme underlying the purpose of Shariah maqasid science is to maintain a community sitemap and a continuous system improvement that emphasizes human improvement [14]. both individually and as a society.

In the poetic system of public policy, it is interesting to review Some important points that are the object of ongoing individual improvement:

\section{Aqidah improvement}

Aqidah is the cornerstone of human thinking, develops the mind for the repair of beliefs, avoids misunderstandings, investigates the facts, discovers truth and avoids wrongdoing, and prepares itself for learning good and right behavior [15].

\section{Mind Improvement}

The refinement of thought in question is the refinement of the mind that is sensitive to the conditions of life, which in turn results in knowledge [15].

\section{Behavior Improvement}

Behavior refinement is an improvement on belief and thinking. Her mind, her thoughts and her beliefs are healthy and her actions are right [15].

Further on society, according to Ibn as Syur, there are two important parts of Islamic society's rule system: First, the system that governs human relations. Second, the system that preserves unity amid the differences between elements of society.

The first instrument or element of the system is the glory of morality, justice, honesty, unity and happiness (loving, advising, maintaining good relations, and dignity). As for the second instrument of the system is happiness, freedom, showing the truth, justice, budget and community savings.

The ultimate goal of policy politics is to have a continuous systemic improvement in both the individual and society, and the refinement of the human mind, mind, understanding, and consciousness to be the initial foundation of all such refinement activities [15].

\section{CONCLUSION}

In the current state of unresolved issues is still the practice of corruption for personal or group gain (ghanimah), this is due to the failure to establish Islamic values and ways of thinking that incorporate Islamic goals, thus damaging the moral, social system society and the economic gap.

The need for fundamental and philosophical and practical improvements in politics and politics. If politics has the meaning of preserving (ri'ayah), improving (ishlah), upholding (taqwim), giving direction or direction (irises) and educating or advancing, then there is a fundamental 
similarity to the meaning of Islamic maqasid, namely Politics and Islamic maqasid emphasizing improvement continuous in systems or rules related to individuals and societies, so that political goals and Islamic maqasid can be achieved to produce culture as well as social engineering tools that produce individuals and the growing quality of their education, morals and beliefs.

Politics should mean the instrument for establishing great values and common interests. Political morality is a very high morality because it includes personal (spiritual-transcendental) character, social morality, environmental degradation, and concern for the whole nation and humanity. It is appropriate to return to the political meaning of meaning, basically, po 1 duck conserve, politically correct, give political guidance for mankind. The improvement of education and way of thinking has been the key element in Islamic maqasid and politics that shaped the character and culture of individuals and societies to achieve mutual benefit in national and national life.

\section{REFERENCES}

[1] J. O. Voll, "Islamic Politics: Continuity and Change in the Modern World", Yogyakarta: The Titian Divine Press, pp. 27, 1997.

[2] J. L. Esposito, "Islam the Straigh Path", Jakarta: Paramadina, $1^{\text {st }}$ ed., pp. 221, 2010.

[3] M. A. Karim, "History of Islamic Thought and Civilization", Yogyakarta: Bagaskara, $5^{\text {th }}$ ed., pp. 25-33, 2014.

[4] M. Q. Shihab, "Says the Qur'an: The Function and Role of Revelation in Public Life", Bandung: PT. Mizan Library, pp. 378, 2013.

[5] S. H. Nasr, "The Heart of Islam: The Universal Messages of Islam for Humanity", Bandung: Mizan Library, pp. 237, 2003.

[6] J. Auda, "The Origins of Islamic Law Through the Syariah Maqasid", Bandung: Pt Mizan Library, 2015.

[7] M. T. I. As-Syur, "Maqasid as-syari'ah alIslamiah", Vol. I, pp. 411.

[8] I. Manzhur, "Oral al-'Arab", Baerut: Dar Sadir, Vol.6, pp. 108.
[9] A. Halim, "Islamic Relations, Politics and Power", Yogyakarta: Lkis, $1^{\text {st }}$ ed., pp. 23-24, 2013.

[10] Z. Qodir, "Sociology of Islamic Politics: Contesting Political Islam and Democracy in Indonesia", Yogyakarta: Student Library, paint I, pp. 1, 2012.

[11] M. A. al-Jabiri, "Al-Aql as-siyasi al-'Arabi”, Bairut: Markaz Dirasat al-Wahdah al'Arabiyah, $4^{\text {th }}$ ed., pp. 15, 2000.

[12] A. M. As-Syarofi, "Marji'iyat alIslam as Siyasi", Tunisia: At-Tanwir, pp. 8, 2014.

[13] A. Balqaziz, "An Nubuwwah wa As Siyasah", Bairut: Markaz Dirasat al-Wahdah al'Arabiyah, pp. 42, 2011.

[14] M. T. I. Ash-Shur, "Maqasid as-syari'ah alIslamiah", Vol. 1, pp. 515.

[15] M. T. I. Asy- Syur, "Usul al-Nidhom al-Ijtima 'fi al-Islam”, pp. 51. 